\title{
An Investigation into Gender Bias in the Employment Institutions
}

\section{Caroline Morris *}

This paper describes part of the results of a research project undertaken at the Employment Institutions. The purpose of this research was to consider whether, and if so, in what way, the Employment Court and the Employment Tribunal contribute to the general position of greater disadvantage experienced by women workers since the introduction of the Employment Contracts Act. This paper examines reported decisions of the Court and Tribunal over the 1991-1994 period, focusing on personal grievances, and concludes that while the employment institutions' decisions themselves do not disclose a pattern of gender bias, there is evidence of gender bias in the awards made to parties, particularly in awards compensating for humiliation, loss of dignity and injury to the feelings of the employee.

\section{Introduction}

Prior to the enactment of the Employment Contracts Act ("the Act" or "the ECA"), there was much speculation concerning the impact the Act would have upon women. Since the passage of the Act in May 1991, a large literature has been amassed documenting its effect on women: little of it positive. The ECA, we are told, according to one extensive study, "does not offer any advantage to women workers and .... in fact, it has clearly disadvantaged women workers" (Hammond and Harbridge, 1993: 28). The contribution of the Act itself to women's worsened employment situation has been well debated, researched and recorded (Hill and du Plessis, 1993; Wilson, 1994).

The purpose of this paper, however, is not to re-present these findings in an alternative form. Rather, this research investigates whether the employment institutions set up by the ECA do themselves contribute to the gender bias experienced by women under the new employment law regime.

Similar research on a much wider scale has been undertaken overseas, including several states of the USA, various provinces of Canada, and some states of Australia. Commonly known as "gender bias task force" reports, these reports have revealed a disturbingly pervasive trend of discrimination against women, both overt and systemic, existing in the justice systems of the state or province concerned, on the part of judges, court staff, police and other lawyers. This paper seeks to parallel their investigations on a reduced scale, looking at employment institutions' decisions in an attempt to discern whether or not gender bias exists in New Zealand's employment institutions. 
"Gender bias" is a term often used with little precision attached to its meaning. Following the approach of many of the gender bias task forces, this report assigns a structural meaning to gender and gender bias. "Gender" means more than "biological differences between women and men. It includes the ways in which those differences, whether real or perceived, have been valued, used and relied upon to classify women and men and to assign roles and expectations to them." (ALRC, 1993: 25). Using Mahoney's definition for the Australian Law Reform Commission (1993: 26), gender bias in the law occurs when there is:

\begin{abstract}
[B]ehaviour or decision making by participants in the justice system which is based on, or reveals reliance on, stereotypical attitudes about the nature and roles of men and women or of their relative worth, rather than being based on an independent valuation of individual ability, life experience and aspirations... . It exists when issues are viewed only from the male perspective, ... when problems of women are trivialised or oversimplified, when women are not taken seriously or given the same credibility as men.
\end{abstract}

It is important to recognise that gender bias can stem not only from the actions of individual decision-makers but can be present in the structure of institutions and their practices themselves. Thus gender bias can manifest itself in many ways: through awards of compensation; through sexist comments or treatment; by glossing over the different working experiences of men and women and failing to see how these might have had an impact on the case; and through the very processes of dispute resolution used by the employment institutions.

\title{
Methodology
}

Due to the difficulties of creation, compilation, and analysis inherent in a survey of those with experience in appearing before the Court and Tribunal (both as advocates/counsel and parties), in addition to the problems of obtaining a representative sample large enough to derive statistically significant conclusions, as well as overall time constraints, it was decided to forego this option in favour of a selective analysis of Tribunal and Court decisions over the period 1991 to 1994 . Thus, the employment institutions were subject to an investigation of what they present for the record rather than presenting a mosaic of the impressions of those who have participated in the Court and Tribunal's dispute resolution processes.

It should be noted that as only reported decisions were considered for the quantitative analysis section, the following discussion will not be fully representative of Tribunal decisions, given the low rate of reporting for these decisions. The parameters of this paper were further narrowed by deciding to concentrate on personal grievance decisions and unjustified dismissal cases in particular. The later qualitative analysis, which focuses on decisions which may particularly affect women, considered both reported and unreported cases, and allows for discussion of gender bias in its wider institutional context.

The cases on which this paper is founded were taken from: firstly, a consideration of the Employment Reports of New Zealand (ERNZ) volumes from 1991 to 1994, backed up by a specific search for cases indexed under "discrimination - sexual"; "personal grievance" and "sexual harassment" for the same period; and secondly, reported and unreported cases 
retrieved from the Employment Institutions" database using the phrases "sex discrimination" and "sexual harassment" and the related sections of the ECA.

The most wide-ranging search was that of the ERNZ volumes, which considered all areas under Parts III and IV of the Act. This covers acts for lost wages, reinstatement, compensation (humiliation and loss of benefit) and disciplinary action in sexual harassment cases (Part III), as well as orders relating to the enforcement of contracts - recovery of wages, compliance orders and penalties for breach of contract (Part IV). However, it soon became apparent that the number of reported decisions under Part IV was negligible; moreover, the parties to these types of cases were, for the most part, employer organisations and unions, which gave little scope for any investigation of the role that gender might have played in the ultimate decision. Thus a decision was made to concentrate on the Part III decisions only for analysis of gender bias.

In the analysis of cases from the employment institutions database, it was decided to look at cases, which, by their nature, would be more likely to have a gender component presenting itself for examination. These were: cases considering sex discrimination actions (s.28); and sexual harassment cases (ss.29, 35, 36 and s.40(1)(d)). Personal grievance cases on their own, especially the numerous unjustified and constructive dismissal actions, were filed on the database in varying formats, and, as the sex of the parties was not always mentioned, this made any comparative investigation of personal grievance cases from a gender perspective incomplete and impractical. Therefore, the comparative consideration of personal grievance cases was confined to decisions reported in ERNZ, while supplementing it with cases with a more obvious gender factor from the employment institutions reported and unreported cases database.

\section{Quantitative analysis of Court and Tribunal decisions}

Reported decisions of the employment institutions were considered firstly for signs of overt gender bias. This was done by creating a comparative matrix of decisions "for" and "against" women and men. Decisions included not only legal and factual issues decided in favour of the plaintiff or respondent but also other questions such as the jurisdiction of the court, leave to appeal and appeals on quantum. The purpose of this study was to see (at an approximate level) whether any trend of the sex of the parties influencing the result became apparent. The figures indicate the percentage (with actual numbers in brackets) of decisions made in favour of one gender or against out of a total of decisions made concerning that gender. Figures sometimes represent more than the actual number of cases decided as a case decided in favour of a woman may also be a case decided against a man. At this level no distinction was made as to the status of the party. 
Table 1: Decisions for/against by gender

\begin{tabular}{||ccccc||}
\hline \hline \multicolumn{2}{|c}{ IN FAVOUR } & \multicolumn{2}{c||}{ AGAINST } \\
1991 & $69 \%(1)$ & $63 \%(12)$ & WOMEN & MEN \\
1992 & $44 \%(8)$ & $77 \%(27)$ & $31 \%(5)$ & $37 \%(7)$ \\
1993 & $80 \%(12)$ & $83 \%(38)$ & $56 \%(10)$ & $23 \%(8)$ \\
1994 & $59 \%(13)$ & $79 \%(42)$ & $20 \%(3)$ & $17 \%(8)$ \\
\hline
\end{tabular}

As this table shows, there do not seem to be any obvious trends in decisions from a gendered point of view. Men and women were almost equally likely to win their cases in 1991 and 1993, with the advantage changing from women to men between those two years by six percent in favour of women to three percent in favour of men. In 1992 and 1994, there were large gaps in the percentage of men and women who succeeded in their actions. However, this did not remain stable, but swung from a 33 percent difference in 1992 to a 20 percent gap in 1994. Not only does the likelihood of winning one's case shift between the sexes from year to year, but the percentage difference of those succeeding or failing changes at an inconsistent rate from year to year. Given the widely varying figures here, the only sensible conclusion to draw from this analysis is that gender does not appear to influence the result of the decision at this basic level.

Further analysis was then undertaken to see whether the decisions of men and women for example in a managerial capacity were likely to be overturned or upheld according to gender.

Table 2: Treatment of managerial decisions made by men and women

\begin{tabular}{||ccccc||}
\hline & \multicolumn{2}{c}{ DECISION OVERTURNED } & \multicolumn{2}{l||}{ DECISION UPHELD } \\
& WOMEN & MEN & WOMEN & MEN \\
1991 & 1 & 16 & 1 & 9 \\
1992 & 1 & 25 & 1 & 17 \\
1993 & 1 & 18 & 1 & 1 \\
1994 & 1 & 20 & 1 & 4 \\
\hline
\end{tabular}


Clearly, there was little analysable data concerning the employment institutions' treatment of decisions of women. However, this may not necessarily be due to a lack of women in managerial positions. Anecdotal evidence from Tribunal members indicates that Tribunal mediations see a significant number of cases concerning the decisions of women in managerial and supervisory roles - mainly in rest homes and hairdressing salons. However, as mediations are confidential this makes it difficult to make comment regarding the influence of gender on the result of the decision. Nevertheless, it can be noted that there is no clear trend displayed concerning the likelihood of a man's managerial decision being overturned or upheld over the five year period. Such decisions appear to turn on their facts and it is likely that were more data available concerning women, a similar non-patterned result would also become apparent.

An analysis was then made according to the remedies available to parties under Part III of the Act.

\section{Section 40(1)(a): Reimbursement}

Under this section parties may be awarded "a sum equal to the whole or any part of the wages or other money lost by the employee as a result of the grievance". Section 41(1) also provides for the payment of lost remuneration to the employee. Awards made under both sections of the Act were considered together. It should be noted that the table does not contain data from all awards of lost wages reported from 1991 - 1995 as in some cases a monetary amount was not mentioned, the Tribunal member or judge preferring to make the award in terms of time for example "three months wages". The data was also skewed by some very high awards made in a few cases such as Trotter $v$ Telecom Corp. ${ }^{1}$ The data should also not be read on a per case, but rather on a per capita basis, as some cases had multiple parties.

Yet again the data provides little help in discerning whether or not a gender bias trend exists in awards of lost wages made by the employment institutions. From an overview of all the cases examined, it does seem that women are awarded lower amounts pursuant to this section than are men. However, in making awards, the employment institutions are tied to the statutory formula of the awardee's actual wages. As women on average earn less than men, this naturally filters through into the wages awards made by the employment institutions. Despite this observation, the statistics again show no consistent pattern from which one might be able to draw a conclusion of institutional gender bias, however slight. In 1991, the average award for women was less than that for men, but this was reversed in 1992 . Women were awarded considerably less on average than men in $1993,{ }^{2}$ and just over a third of the men's average in 1994. The median award also varied a great deal. While the median for men increased each year, the median award for women alternated between approximately $\$ 4,000$ and $\$ 7,000$ each year. The one consistent point was the fact that men occupied both the

2 Note that this was skewed by the Trotter case. Without this case, the average award made to men in 1993 would have been $\$ 9,500.13$, only $\$ 700$ above the women's average. 
highest award and lowest award category in each year. Thus, while a woman was never awarded more than all awardees, nor was she ever awarded less than all other awardees.

Where reimbursement was specified in terms of time, the most common period mentioned was three months, for both sexes.

Table 3: $\quad$ Awards made under s.40(1)(a) and s.41(1)

\begin{tabular}{|c|c|c|}
\hline & WOMEN & MEN \\
\hline \multicolumn{3}{|l|}{1991} \\
\hline Average & $\$ 6,852.65$ & $\$ 7,449.70$ \\
\hline Range & $\$ 7,460.66-\$ 6,330.00$ & $\$ 19,824.90-\$ 1,853.00$ \\
\hline Median & $\$ 6,809.97$ & $\$ 3,200.00$ \\
\hline \multicolumn{3}{|l|}{1992} \\
\hline Average & $\$ 7,492.18$ & $\$ 6,061.60$ \\
\hline Range & $\$ 22,829.00-\$ 1,700.00$ & $\$ 26,036.00-\$ 430.17$ \\
\hline Median & $\$ 3,957.68$ & $\$ 5,000.00$ \\
\hline \multicolumn{3}{|l|}{1993} \\
\hline Average & $\$ 8,822.79$ & $\$ 39,020.66$ \\
\hline Range & $\$ 17,388.36-\$ 2,080.00$ & $\$ 334,226.00-\$ 1,706.40$ \\
\hline Median & $\$ 7,000.00$ & $\$ 5,731.20$ \\
\hline \multicolumn{3}{|l|}{1994} \\
\hline Average & $\$ 3,421.19$ & $\$ 9,874.43$ \\
\hline Range & $\$ 4,491.96-\$ 1,442.00$ & $\$ 22,500.00-\$ 800.00$ \\
\hline Median & $\$ 4,329.60$ & $\$ 7,487.00$ \\
\hline
\end{tabular}

\section{Section 40(1)(b): Reinstatement}

The Labour Relations Act provided that reinstatement was to be the primary remedy where it was included in the remedies sought by a worker in a personal grievance. ${ }^{3}$ The ECA gives reinstatement equal priority with the other remedies under s.40. It would appear that this has led to a considerable decrease in the number of reinstatements ordered as part of a personal 
grievance settlement. Cases from 1991 - 1994 contained a total of nine reinstatements. Note that this section does not consider reinstatements through interim injunctions which are obtained via the Court's equity and good conscience jurisdiction under s.104(3). ${ }^{4}$

There were no cases of reinstatement in 1991, three in 1992 (all men), none in 1993, and then six in 1994 (one woman, five men).

In terms of the pasitions held by the men who were reinstated, there appears to be a slight trend towards reinstatement of white collar workers ${ }^{6}$ (although a meatworks boner, ${ }^{7}$ a night watchman ${ }^{8}$ and a sewer patrolperson ${ }^{9}$ were also reinstated). Amongst those reinstated were two assistant managers, ${ }^{10}$ a senior air traffic controller ${ }^{11}$ and a bank manager. ${ }^{12}$ Of the two women reinstated over this period, both were teachers. One was the newsworthy Hobday ${ }^{13}$ case at Timaru Girls' High, the other was also a secondary school teacher. ${ }^{14}$

4 For instance, $X$ v Y Ltd \& NZ Stock Exchange [1992] 1 ERNZ 863 and Nansen v Wellington City Council [1992] 1 ERNZ 617.

5 This decision confirmed the reinstatement of Annabel Hobday to her position of Principal at Timaru Girls' High School. Thus, although there were cases in both 1993 and 1994 awarding her the remedy of reinstatement, only one decision is counted for the purposes of the total, as the 1993 decision was reinstatement by interim injunction.

6 Note that those reinstated by interim injunction also tended to be white collar workers as well.

7 Fortex Group Ltd v Laxton [1994] 1 ERNZ 402.

$8 \quad$ Robertson v Port Nelson Ltd [1994] 1 ERNZ 976.

$9 \quad$ Hobbs v North Shore City Council [1992] 1 ERNZ 32.

10 Blomfield v Kentucky Fried Chicken [1992] 1 ERNZ 126; Hildred v Newmans Coach Lines Ltd [1992] 3 ERNZ 165.

11 Airways Corp of NZ Ltd v Brunton [1994] 1 ERNZ 352.

12 Lavery v Trust Bank Wellington Ltd [1994] 2 ERNZ 339.

13

Hobday v Timaru Girls' High School Board of Trustees [1993] 2 ERNZ 146; [1994] 1 ERNZ 724.

14

Shaffer v Gisborne Boys' High School Board of Trustees [1995] 1 ERNZ 94. 
Although the sample is small, it appears that women are awarded reinstatement less often than men are. This may be because women seek it less often than men do, maybe finding alternative employment more easily, or perhaps because they more often want to avoid a return to a place of unpleasant memories. ${ }^{15}$ Obviously, by the time a case has reached the point of adjudication, the relationship between the parties will not be the best. The employment institutions do not have the power to award remedies a personal grievant has not sought.

\section{Section 40(1)(c): Compensation}

There are two kinds of compensation awarded under s.40(1)(c). Compensation under s.40(1)(c)(i) is for "humiliation, loss of dignity and injury to the feelings of the employee", while s.40(1)(c)(ii) compensates for the "loss of any benefit, whether or not of a monetary kind, which the worker might reasonably have been expected to obtain if the personal grievance had not arisen." Unfortunately for the investigations of this report, decision-makers did not always specify whether the compensatory sum awarded was under s.40(1)(c)(i) or s.40(1)(c)(ii) or an aggregate of both. For tabular purposes, compensation was recorded simply as an award made under s.40(1)(c). However, since each subsection clearly has a different purpose, the amount awarded consequently reflects this. Comparisons of the awards made are therefore meaningless unless it is known whether the award was made to compensate for humiliation or loss of benefit. Thus in the analysis which follows the data presentation focuses only on those cases where the purpose of the compensation was indicated by the decision-maker. It should be noted that this tends to narrow the range of decisions available for analysis somewhat.

Again, the compensation awarded under this section appears to follow no pattern that can be tied to gender. While in 1991 and 1992 men's and women's average awards were very similar, and the midpoint awarded the same, this changed in 1993 where the average award made to men was five times that for women, and the median amount of compensation for men was three times higher than the women's median. However, this state of affairs was reversed the following year when the men's average was two-fifths of the women's average, and the women's median almost twice that of men.

Compensation for loss of benefit appears to be linked to income and other non-discretionary factors. Therefore, it was decided to focus on compensation levels for humiliation, loss of dignity and injury to feelings, as it is here that the possibility of gender bias seems more likely as there is no statutory formula for deciding the level of award.

15 There appears to be no research on this point. However, an overview of the employment institutions database reveals that for the period 1991 - 1995 women seeking reinstatement were almost as equally likely to be successful as not (data on file with author). There was one case recording the abandonment of reinstatement as a remedy by woman: Ter Haar v Eliot-Cotton Associates [1993] 1 ERNZ 371. There was also one case of a man refusing an employer's offer of reinstatement: Finau v Carter Holt Building Supplies [1993] 2 ERNZ 971. 
Table 4: Awards of compensation made under s.40(1)(c)

\begin{tabular}{|c|c|c|}
\hline & WOMEN & MEN \\
\hline \multicolumn{3}{|l|}{1991} \\
\hline Average & $\$ 5,916.66$ & $\$ 5,745.00$ \\
\hline Range & $\$ 13,000.00-\$ 1,500.00$ & $\$ 10,000.00-\$ 1,500.00$ \\
\hline Median & $\$ 5,000.00$ & $\$ 5,000.00$ \\
\hline \multicolumn{3}{|l|}{1992} \\
\hline Average & $\$ 4,910.30$ & $\$ 5,427.78$ \\
\hline Range & $\$ 8,000.00-\$ 400.00$ & $\$ 10,400.00-\$ 1,500.00$ \\
\hline Median & $\$ 5,000$ & $\$ 5,000.00$ \\
\hline \multicolumn{3}{|l|}{1993} \\
\hline Average & $\$ 2,450.00$ & $\$ 10,684.21$ \\
\hline Range & $\$ 5,000-\$ 1,500.00$ & $\$ 50,000.00-\$ 3,000.00$ \\
\hline Median & $\$ 2,000.00$ & $\$ 6,000.00$ \\
\hline \multicolumn{3}{|l|}{1994} \\
\hline Average & $\$ 15,500.00$ & $\$ 8,916.67$ \\
\hline Range & $\$ 37,500.00-\$ 3,500.00$ & $\$ 32,000.00-\$ 1,000.00$ \\
\hline Median & $\$ 10,000.00$ & $\$ 6,000.00$ \\
\hline
\end{tabular}

Although the data table presents the impression that this area is free from gender bias, what is more interesting is what the statistics do not reveal. It appears that there is an unstated system in the Tribunal of tying awards of compensation for humiliation and so forth to the complainant's level of income. Possibly this practice has been influenced by the comments of Chief Judge Goddard: "Normally the first head for which compensation is awarded [i.e. s.40(1)(c)(i)] is the loss of opportunity to work at the job ..." in Cain v HL Parker Trusts. ${ }^{16}$ While this on its face appears neutral, it in fact discriminates against women. This is because women's earnings tend to be lower than men's. Therefore, any system which uses a discriminatory benchmark to assess the level of compensation for women and men will result in women's compensation being assessed at a lower rate. Not only is this practice of concern due to the flow-on sexism inherent in this standard, but the appropriateness of this standard is also questionable.

Clearly the hurt suffered by the employee will in some way be related to his or her position and thus income, even if only at the very basic level of being in an aggrieved position due to one's status as an employee. Yet it is not so clear that the way to assess the humiliation and injury to feelings suffered by a personal grievant is by reference to that person's income. 
By this system, the award of compensation becomes removed from consequences it was supposed to be compensating for. Income may not be relevant at all to the way someone may react when unjustifiably dismissed or sexually harassed.

There are also no guarantees that a person occupying a managerial position will need more compensation for injury to feelings than may someone who works on the factory floor. There is the unstated inference that those who earn less have feelings that are easily assuaged, and so less is required to soothe them. Again, as women are clustered into a small range of lowpaying occupations, this devalues the work-related hurt of women arising from a personal grievance.

It is suggested that awards of compensation under s.40(1)(c)(i) should focus more closely on the actual circumstances that gave rise to the personal grievance. Greater emphasis should be placed on the actual reactions and feelings of the personal grievant, rather than lining up compensation with the person's income. A more individualised and contextual assessment of the hurt the individual has suffered would go some way towards negating the gender bias ingrained in this system. Although the employment institutions claim to uphold this approach, it seems that it is not necessarily always practised. ${ }^{17}$

Another area for concern arises when the amounts awarded to women for injury to feelings are read in conjunction with the comments of decision makers regarding the level of emotional harm suffered as a result of the personal grievance. Even allowing for differences amongst decision makers, the overall impression is that women's harm is compensated at a lower level than men's, even when the effects of the matters leading to a personal grievance have been similar or more serious.

For example, in 1991, a woman described as being "severely traumatised" and having undergone a "great deal of distress" after an unjustified dismissal was awarded $\$ 5,000$ compensation under s.40(1)(c)(i) ${ }^{18}$ while in the same year a man also unjustifiably dismissed was awarded $\$ 3,000$, even though the Tribunal member commented "there was surprisingly little evidence about the humiliation, loss of dignity and injury to Mr Roderique's feelings."19 The award was justified on the basis that all dismissals are "naturally humiliating" and that his employer had made a hurtful comment about Mr Roderique, mitigated by the long time allowed before Mr Roderique actually had to leave the company. ${ }^{20}$ Comments of this nature make one wonder what amount would have been awarded as a token gesture to a woman who had suffered only minimal hurt.

17 See $P A O^{\prime}$ Connor v Brass [1994] 1 ERNZ 388, 396.

18 Math v NZ Printing and Related Trades IUOW [1991] 2 ERNZ 871, 877.

19 Roderique v Port FM Ltd [1991] 3 ERNZ 825, 837.

20 Roderique, at 838. 
It is tempting to ascribe this state of affairs to the employment institutions coming to terms with the new regime set up by the ECA. However, this does not seem to provide an adequate explanation. In 1992, another unjustified dismissal case saw \$7,000 compensation awarded under s.40(1)(c)(i), where again the male grievant had again "adduced little evidence .... on the extent of the humiliation, loss of dignity and injury to feelings." ${ }^{21}$ A woman in similar circumstances, providing "non-existent or meagre" evidence of the injury to her feelings (although the Tribunal acknowledged that she had suffered "some distress" and had had "quite a shock"), was awarded only $\$ 4,000 . .^{22}$

This pattern of the differing valuations of the hurt suffered by men and women continued in 1992. In two cases where the parties were both awarded $\$ 8,000$ compensation for humiliation and loss of dignity, Mr Baussmann's evidence stated that he "felt uncomfortable", he had not been treated with "proper courtesy", while the Tribunal did not elaborate on its reasons for making the award other than stating that it accepted the evidence of his wife, ${ }^{23}$ while Mrs Harding, who was dismissed by her ex-husband, found the whole episode "deeply distressing." 24 The complainants appear to have had distinctly different experiences, yet this is not reflected in their awards.

This trend exhibits itself consistently over the four years under investigation. The employment institutions claim to uphold the "eggshell skull" rule, commenting in $1994::^{25}$

That means that different sums of compensation might be awarded to two different grievants unjustifiably dismissed on exactly the same facts. The two grievants may be constructed with two different personalities. One personality may be more sensitive to the effects of the dismissal ... The question is not the degree of cause, but the degree of [effect] on the feelings of the uniquely constituted personality of the employee.

Having said this, the Tribunal went on to award the "extremely disturbed" Ms Brass in that case $\$ 3,500$ for what it described as a "major injury to her feelings". On appeal, the award was upheld, and the presiding judge concluded that she was "quite shattered emotionally by her experience" describing it as "very frightening" (her mentally disturbed employer's actions had resulted in her constructive dismissal). Two months later, a motor mechanic was awarded

Forbes v Colonial Mutual [1992] 1 ERNZ 32, 51.

Prebble v Coastline FM [1992] 1 ERNZ 52, 62.

Baussmann v Trilogy Business Systems Ltd [1992] 1 ERNZ 386, 395-397. 
$\$ 3,750$ as compensation for his hurt feelings in an unjustified dismissal case, with no discussion of the effect on the employee. ${ }^{26}$

It is difficult to see what could account for these very similar awards in strikingly different circumstances, given the supposed commitment to taking into account the actual effect on the employee.

In 1994 the Tribunal awarded $\$ 30,000$ compensation to a gay man who was accidentally "outed" (i.e. his homosexuality was disclosed without his consent) at work to compensate for the homophobic sexual harassment he was subject to (including threats to do him bodily harm), leading to continuing insecurity at work and eventually resulting in his transfer to Australia. ${ }^{27}$ While this decision is laudable from the point of view of taking sexual harassment seriously, it is cause for concern that the amount awarded in 1995 to Gaye Davidson in the Christchurch Civic Creche case was also $\$ 30,000{ }^{28}$ Ms Davidson was subject to police investigation and stood trial for child abuse allegations, received a bullet in the mail with her name engraved on it and has had to give up her chosen career and retrain in her late forties. ${ }^{29}$ While both cases are undeniably serious, it is questionable that the disruption of Mr L's career and the disruption of Ms Davidson's life were deserving of the same amount of compensation.

Discretionary compensation awards allow institutions to (amongst other things) decide how much people are worth. It seems clear that there is a distinct pattern in the employment institutions of valuing the hurt experienced by women as being worth less than the hurt experienced by men. Women seem to have to experience deeper levels of injury to their feelings than men do, in order to receive the same level of compensation and are compensated less when they experience similar effects from a personal grievance as men do. Even if it could be explained by saying that the employment institutions expect women to be more emotional than men and so rank their outward show of emotion with the lesser, more contained reactions of men as actually being of equal effect, this relies on sexist stereotypes in making decisions, abstracts the individuals from their experiences, devalues and trivialises the harm suffered by women and uses a male standard as a yardstick for compensation. This is gender bias.

The majority of this analysis centred on awards for unjustified and constructive dismissal, these being the most common causes of claims for compensation under s.40(1)(c)(i) However, dismissals are not the only area where this undervaluing of women occurs. Davis

$26 \quad$ Van Leeuwen v Skedden [1994] 1 ERNZ 624.

27 $L v M[1004] 1$ ERNZ 123. This amount comprised $\$ 25,000$ for hurt and humiliation and $\$ 5,000$ for the sexual harassment. Another $\$ 2,000$ was awarded for resettlement costs. 
(1994: 32), remarks on a similar trend in sexual harassment cases, pointing out a "measurable inequality of treatment between .... women who are sexually harassed and .... men dismissed for sexually harassing behaviour." She comments that compensation awards under s.40(1)(c)(i) have been "unfairly generous to male harassers and unfairly low in the case of complainants of sexual harassment" (1994: 41).

\section{Section 40(1)(d): Recommendations concerning sexual harassment}

This section has been little-used in both the reported and unreported cases decided by the employment institutions. Over the years 1991 - 1994 recommendations under this section have been made twice, ${ }^{30}$ once in $A v Z^{31}$ and also in $L v M$. In the latter case, the Tribunal recommended a general educative programme focusing on the sexual harassment of gay and lesbian staff. In $A v Z$, the Tribunal recommended that it. ${ }^{32}$

May be wise in any establishment involving the public in numbers and employing young women that .... [it] should firstly liaise with the Human Rights Commission or similar organisation over their sexual harassment programmes and courses. Secondly, provide posters and brochures within the workplace environment for staff. Thirdly, put in place a sexual harassment complaints procedure with opportunity for independent referees.

Laudable though these recommendations are, the passage unfortunately displays some common misconceptions about the nature of sexual harassment, namely that sexual harassment only happens to young women, thereby dismissing the reality that sexual harassment happens to women of all ages, and inferring that sexual harassment is more likely to occur where there is greater contact with the public, which glosses over the fact that most sexual harassment claims are against employers or co-workers.

In $A \vee Z$, the Tribunal also noted that it did not appear to have the "extensive" powers to order remedial action as did the Human Rights Commission. Such orders were made in Proceedings Commissioner $v$ NZ Van Lines, ${ }^{33}$ a decision under the Human Rights Commission Act 1977, not the ECA (although reported in ERNZ). However, on appeal to

The only other case (reported and unreported) to mention s.40(1)(d), Sloggett v Taranaki Health Care [1995] 1 ERNZ 553, did not actually concern recommendations made under this section but simply highlighted the options available to an employer, with the comment that these were "by no means an exhaustive list". 
the High Court, Smellie J considered that s.38 of the HRC Act did not include the power to order general anti-discrimination programmes as had been done in that case. ${ }^{34}$

Education plays a large part in transforming attitudes generally. It is an important tool in the goal of reducing employment-related sexual harassment in New Zealand. It is therefore unfortunate that the provisions of the ECA which might be used to recommend educative programmes are so rarely used. This was noted by the Court in 1993 , which proposed that ${ }^{35}$

\begin{abstract}
When the Tribunal finds that an employee has been sexually harassed in the employee's employment and the person or persons responsible is or are known or identifiable, the Tribunal should ordinarily recommend to the employer that it arrange rehabilitative counselling for that person or persons. To enable this to be done effectively, I have asked the chief executive officer to ascertain and make available to Secretaries of the Tribunal information concerning the providers of such counselling services in the main centres.
\end{abstract}

It is unclear why no recommendations pursuant to $s .40(1)(d)$ have been made since this comment was made by the Court. The fact that the provisions are not mandatory and give recommendatory powers only to the decision-maker should not be seen as an excuse to shy away from making a recommendation at all.

It also should be noted that neither of the two cases which considered s.40(1)(d) employed it to make recommendations concerning a specific harasser (or group of harassers). Although in both cases the personal grievants had left their workplaces, this should not be seen as a solution to the problem. While efforts to stamp out workplace culture which condones and/or encourages sexual harassment are to be encouraged, recommendations concerning the behaviour of certain persons should also be considered more frequently.

\title{
Selective qualitative analysis of Court and Tribunal decisions
}

This section focuses on the employment institutions' treatment of issues which are of particular relevance to women: discrimination and sexual harassment.

\section{Discrimination}

Discrimination on the basis of sex is a ground for a personal grievance under s.28 of the Act Decisions considering this section are few. The very small number of cases here makes comment concerning any trends of gender bias or otherwise difficult. Nonetheless, they are mentioned here for the sake of completeness.

${ }^{34} \quad$ NZ Van Lines, at 150. 
One case was decided in 1991, concerning an employer's policy that required female employees to retire at 60 and males at $65^{36}$ Pursuant to the passage of the Human Rights Commission Act 1977, the employer changed its policy and required all employees to retire at age 60 . Those who were members of superannuation schemes were permitted to retire at 65. The grievant's claim of sex discrimination in her dismissal was rejected on the basis that the distinction was no longer between male and female employees but between those who were members of superannuation schemes and those who were not. Her claim that she would not have been dismissed but for her sex therefore failed.

In the one case concerning a claim of discrimination on the basis of marital status, ${ }^{37}$ decided in 1993, the Tribunal considered the claim of a storeperson who was dismissed because her husband held a managerial position for a rival company. It determined that the term "marital status" in the Act was wide enough to include the characteristics of one's spouse and upheld her claim accordingly. An earlier case which held that a marital relationship was not relevant to a woman grievant's dismissal was deemed to be inapplicable. ${ }^{38}$

Another case which attempted to rely on the ground of discrimination on the basis of sexual orientation was dismissed as the ECA does not make this a ground for a personal grievance under s. $28,{ }^{39}$ in contrast to the Human Rights Act. This legislative omission lessens employment security for lesbian and bisexual women. The ECA should be amended to make its discrimination provisions consistent with those of the Human Rights Act.

\section{Sexual harassment}

Given the amount of sexual harassment that undoubtedly goes on in the workplace (Joychild, 1993: 58), the number of cases that come before the employment institutions and are available for examination is small. Inquiries to and complaints investigated by the Human Rights Commission on sex discrimination and sexual harassment far outnumber those dealt with by the employment institutions. Several reasons have been posited for this: that HRC procedures are more visible and that sexual harassment is seen as a human rights, not an industrial, issue; that ECA procedures may be seen as inevitably adversarial, in contrast with the HRC's more investigative approach; and that unions [and employers] may be being successful at resolving the problems at workplace level (or alternatively, may be preferring to use the HRC procedures) (Davis, 1994: 29).

House v Northland Area Health Board [1991] 3 ERNZ 913.

37 Eggleston $v$ The Firestone Tyre and Rubber Company (NZ) Ltd (Unreported, Employment Tribunal, Christchurch, 6 September 1993, GM Teen, CT 119/93). Auckland, 6 April 1995, BW Stephenson, AT 102/95). 
It would appear that most sexual harassment cases that come before the employment institutions are settled by mediation. However, all sexual harassment cases considered under the ECA provisions still form only a small part of the total of cases settled each year (even when taking into account the fact that many cases investigated by the HRC are not employment-related) (Swarbrick: 1995: 28). The reluctance of women to bring sexual harassment cases before the employment institutions is cause for concern. This concern may be explained somewhat by considering the fact that for women sexually harassed in their employment, the ECA sections are rather restrictive: liability is only imposed against the employer even where the harassment is carried out by co-workers or clients, ${ }^{40}$ and, in the case of sexual harassment by those other than the employer, liability occurs only when the employer has not taken whatever steps are practicable to prevent a repeat of the sexual harassment by that person. ${ }^{41}$ Thus, in many cases, women may simply not be eligible to use the ECA provisions, whereas the HRC procedures are wider in their scope. Although no blame can be laid at the door of the employment institutions for the narrow application of the ECA in sexual harassment matters, the narrowness of the sections themselves remains a concern, especially as they give the impression that sexual harassment in the workplace is not properly the sphere of employment legislation. Further, HRC procedures come at no cost, while for those without the benefit of union representation, the thought of paying for legal advice may act as a deterrent to taking a case.

While the employment institutions themselves cannot be considered to have contributed to these reasons why women might prefer to take their cases to the HRC, they are not immune from critique of their dealings with the cases that do actually come before them. Davis (1994: 31) concluded that there was considerable evidence of gender bias in this area of the law, including:

analysis of concepts from a male perspective; failure to appreciate and act upon the real life experience of women; underestimation of the effects of decisions on women; reliance on myths about sexual harassment; and failure to recognise unstated assumptions or to scrutinise untested assumptions ... Some decision makers appear neither to understand nor, in some cases, even to accept the basic premise on which the legislation is founded: that sexual harassment is unlawful and can seriously harm women

This documented lack of sympathy on the part of the employment institutions would appear to underscore the decision of many women to prefer the HRC over the employment institutions' procedures. However, in the few years since that comment was made, there appears to have been a significant improvement in the employment institutions' treatment of the sexual harassment cases that have come before them. Although the number of cases remains small, the seriousness with which sexual harassment is now taken by the employment institutions has increased considerably.

40 Compare s.68 HRA, where individuals other than the employer may be made personally liable

41 Section 36(3) ECA, emphasis added. This means that where the complainant is sexually harassed by a succession of co-workers or customers no liability attached to the employer for failing to prevent sexual harassment by a number of people. 
In the 1993 case of $Z v A$, Chief Judge Goddard made some strong statements of principle regarding sexual harassment cases. The Chief Judge said: ${ }^{42}$

... sexual harassment poisons the whole workplace. It is wholly unacceptable and entirely devoid of any redeeming features. It follows that its occurrence can never be met with matters of justification, excuse or mitigation. It is an attack on the basic right that all persons must be supposed to have to pursue their economic wellbeing in conditions of freedom and dignity.

Its victims are invariably women. It is insidious and deceptive in character.

And although it can be nothing more than an approximate indication of the employment institutions' improved treatment of sexual harassment cases, awards of compensation under s.40(1)(c)(i) to grievants alleging sexual harassment have increased notably since 1993 .

For instance, as well as the $\$ 30,000$ award made in $L v M, \$ 15,000$ was awarded in 1994 to a woman who was raped by her employer, ${ }^{43}$ and in two cases where the employer requested sexual favours in return for money (in addition to sexual comments and touching) or job security (as well as indecent exposure and indecent assault), the grievants were awarded $\$ 7,500^{44}$ and $\$ 25,000 .^{45}$

In the five years under investigation, the employment institutions have also removed some of the barriers to making a sexual harassment complaint and carrying it through as a ground for a personal grievance.

For instance the confusion over the appropriate standard of proof in sexual harassment cases laid down in NID Distribution Workers IUOW $v A B \operatorname{Ltd}^{46}$ was cleared up in $Z v A$, the Court holding that the correct standard of proof is the balance of probabilities. The Chief Judge commented:" $[\mathrm{t}]$ here is no reason to place in the way of those who say they have been the victim of sexual harassment any barriers which start with the premise that the complaint is

${ }_{42}$ At 472 . By way of an indication of the rarity of sexual harassment cases, this was the first case to be heard in the Employment Court.

$J v M$ (Unreported, Employment Tribunal, Auckland, 21 July 1994, IM Davidson, At 235/94).

$A \& B v X Y$ Ltd (Unreported, Employment Tribunal, Christchurch, 2 March 1995, DS Miller, CT 25/95). 96/95). 
more likely to be untrue than true." ${ }^{\prime 47}$ All acts of alleged sexual harassment were to be treated with the same degree of seriousness for the purposes of proof.

Previously, it had been understood that complaints to an employer of sexual harassment had to be in writing before the employer was obliged to take action. Such a requirement may be a disincentive for women to make, or pursue, a complaint. However, in the 1994 case of $X$ $v A B$ Co $L t d{ }^{48}$ the Tribunal dispelled this misconception over the use of the word "may" in s.36(1)(b), stating "justice should not be a slave to grammar ... the words [are not] mandatory, they are used in an empowering sense." ${ }^{49}$

\section{Mediation: advantages and disadvantages for women}

Mediation of employment disputes plays a large part in the activities of the Employment Tribunal. In fact, nation-wide, approximately 60 percent of all cases before the Tribunal are mediated, with 85 percent of these being settled, (Gardiner, 1993: 3) although regional differences mean that the total of mediated settlements is considerably higher in some centres. One significant aspect of mediated settlements is that they are confidential. This means that a considerable proportion of all cases that are brought before the employment institutions are unavailable for research scrutiny. Given the small numbers of women appearing in the cases that are available, it would seem that a greater proportion of women than men have their cases resolved at the mediation stage. As mediated settlements appear to form a significant part of women's experiences with the Employment Tribunal, but cannot be analysed for reasons of confidentiality, what follows is a theoretical analysis of the advantages and disadvantages of mediation as a form of dispute resolution for women. However, this section comes with a caveat: it should not be taken as an evaluation of actual Tribunal practice, although naturally what is said here will be of relevance to the issue of gender bias in the employment institutions.

The typical mediation involves a dismissed employee and his or her employer. Over 80 percent of mediations are personal grievances, and of those, 95 percent relate to alleged unjustifiable dismissals (Gardiner, 1993: 4). Eighty-five percent of women are employees, compared to seventy-three percent of men, while eleven percent of men are employers as compared to five and a half percent of women (Ryan, 1993). Thus, in the typical mediation, a dismissed female employee is twice as likely to be facing a male employer than a female one. Whether the typical personal grievance mediation is also more likely to see a female employee than a male one is unclear, given the lack of data relating to the gender of the personal grievants.

47 At 475 . 


\section{The mediation process}

There is no set format for mediation under the Act. However, a similar process is followed by most Tribunal members, although personal styles differ. Mediated disputes are generally resolved quickly; the process is informal, inexpensive, and private. Mediation is a conciliatory form of dispute resolution. It stands in apposition to the adversarial nature of Tribunal and Court adjudication, where the two parties, both hoping to win at their opponent's expense, present their cases to a neutral third party who decides in one party's favour.

\section{What does this mean for women?}

Adjudication has been termed a characteristically "male" way of resolving differences, a microcosm of the "male" nature of the legal system itself. The historical preserve of men, developed without reference to the reality of women's lives and experiences, the legal system is characterised by "hierarchy, linear reasoning .... its fundamental aspiration is objectivity and to that end it separates public from private, form from substance, and process from policy" (Grillo, 1991: 1547). Adversarial dispute resolution is premised on the values of "advocacy, persuasion, hierarchy, competition and binary results"(Menkel-Meadow, 1985: 51) and de-emphasises other values such as collectivity, compromise, subjectivity and personal inter-relationships.

It is unsurprising therefore that research into women's experiences with the modern justice system has come to the conclusion that adversarial methods of dispute resolution are not particularly "women-friendly". Reluctance to expose themselves to such a procedure may well explain the lower numbers of women present in adjudicated decisions in the employment institutions, however personable and well-meaning the decision-maker.

Given this critique, mediation has been posited as an attractive alternative to adjudication. It is inexpensive, which benefits women, who on average, earn less than men do and may be discouraged from taking a case on the basis of costs. Mediation is therefore a way of making the justice system more accessible to greater numbers of women. Although it remains the primary method of dispute resolution in the Tribunal, it is suggested that there be more employment institutions-generated publicity about the availability of mediation and its costs, which might encourage more women employees to consider bringing their disputes to the Tribunal for mediation.

Mediation is also not governed by formal rules of procedure and evidence. This places much more control in the hands of the parties. The grievant has an active role rather than being relegated to a passive observer. Mediation has been hailed as a very empowering form of dispute resolution for women, in that it allows women to be fully involved in the process of resolving their disputes, rather than distancing themselves and acting by remote control by handing their dispute over to a lawyer, bound by formal rules and reliant on his or her speaking skill to win through their point of view.

In contrast to adjudication, mediation does not focus so much on the legal rights of the parties as on the process of working out a "win-win" solution to their dispute. Mediation focuses more on context and less on abstract legal rules, more on the relationship between the parties 
(especially where the employment relationship may be continuing) than their rights. Recent critiques of rights-talk have commented on the way in which isolated discussion of rights can lead to a sense of alienation from the justice system (although see Williams, 1987). Moreover, there has also been much research in the past fifteen years, suggesting that women define themselves in terms of their relationships to others (Gilligan, 1982). If this is so, as a process which operates with a stronger emphasis on the parties' relationship and discourages reliance on caselaw and legal principles, mediation is a method of resolving differences which fits more with women's sense of themselves than adjudication. In that mediation also puts the facts at the centre of the dispute, as opposed to the law, this lessens the chance of gender bias as the reality of women's working lives are uncovered and acknowledged, something which does not always happen when it is the law that is the prime concern.

However, mediation cannot be seen as a cure-all form of dispute resolution for women. Concerns have been raised about the inability of mediation to redress the power imbalance of the parties who come to mediation. Power is situational in the employment relation, and as already noted, women are almost sixteen times more likely to be an employee before the Tribunal than an employer. Power is also intertwined with gender, (MacKinnon, 1987) and women employees are twice as likely to be facing a male employer than a female one. When these two combine, the possibility arises that women will be more compromising than men to their detriment. If the mediator maintains a position of strict neutrality, and does nothing to redress the power imbalance, the disadvantage women experience in adjudication, then mediation fails as a means of empowering women and perpetuates inequality instead.

The flip side of concerns about neutrality is the issue of mediator bias. Generally, the fact that mediations are private is seen as a benefit for both parties, enabling them to make concessions and discuss matters they would not bring up in a public arena. However, the private and informal nature of mediation does allow the mediator to shape the procedure, and possibly the result: for example, a mediator may take an active role, advising the parties on their options and suggesting possible solutions, or he or she may simply chair discussions between them. Mediators have the opportunity to advance certain values by their actions which may harm women or exhibit sexist behaviour by their treatment of the parties which is never exposed to public light.

Overall, mediation has many advantages which adjudication cannot match. However, women going into mediation do not wholly escape the "male" nature of adjudication, for mediation comes with its own dangers which should not be ignored.

\section{Conclusion}

The overt and widespread gender bias documented by the task forces in North America and Australia has not been paralleled by this investigation into New Zealand's employment institutions. The statistical analysis reveals little in the way of the sex of the parties influencing the decision. These non-patterned results indicate that findings of fact and law are made free from considerations of the sex of the parties before the employment institutions. 
However, the awards which accompany these statistics do raise some concerns. While the differentials between men and women in lost wages awards can be explained in part by pointing to their relative differences in earnings, the comments of decision-makers underpinning the awards for humiliation and injury to feelings are troubling. There appears to be a distinct trend of undervaluation of the hurt experienced by women in the events leading to a personal grievance claim. Women seem to have to suffer more than men in order to receive the same amount of compensation, and when the comments discussing worker distress are analysed, similar amounts are made to men and women who experience differing emotional consequences from their personal grievances. This trend is consistent from 1991 1994 and occurs in both unjustified dismissal actions and sexual harassment cases.

The history of the employment institutions' treatment of sexual harassment claims is a chequered one. The poor record documented by Wendy Davis from 1991 - 1993 seems to have improved, with an increase in awards to sexual harassment complainants and some strong supportive comments of personal grievants in this area being made by the Court. The employment institutions have also re-interpreted sexual harassment law, effectively removing some of the barriers to making a complaint and following it through. Nonetheless, the continued reluctance of the employment institutions to make recommendations concerning sexual harassment has been noted.

Finally, the strong reliance in the employment institutions on mediation as a method of dispute resolution is commendable: mediation, being inexpensive, is an accessible form of justice for women who, on average, earn less than men, while its context-oriented format lessens the chance of the reality of women's working lives being subsumed beneath a mass of caselaw and legal principle.

\section{Recommendations}

This paper also makes the following recommendations to further address gender bias in the Court and Tribunal: that to fully reflect the diversity of the public the institutions serve and to lessen the likelihood of gender biased decisions, more female decision makers should be appointed, particularly a woman judge, as "[m]ale judges, in general, do not have the background experience necessary to recognise the male-centredness of law in its subtle and not-so-subtle forms" (Cooney, 1993: 29); that there should be more education of Tribunal members and Court judges to heighten awareness of gender bias occurring; there should be increased Tribunal-generated publicity, particularly as regards mediation, given its benefits for women; and that decision makers should strongly consider increased use of their recommendatory powers under $\mathrm{s} .40(1)(d)$ concerning sexual harassment.

\section{References}

Australian Law Reform Commission (1993), Equality Before the Law.

Benjamin, M. and Irving, H.H. (1992), Toward a Feminist-Informed Model of Therapeutic Mediation, Mediation Quarterly, 10(2): 129-153. 
Cooney, S. (1993), Gender and Judicial Selection: Should there be more women on the Courts?, Melbourne University Law Review, 20-44.

Davis, W. (1994), A Feminist Perspective on Sexual Harassment in Employment Law in New Zealand, Monograph, Wellington: New Zealand Institute of Industrial Relations Research.

Gardiner, R. (October 1993), Mediation of Employment Disputes, Auckland, Address to the Arbitrators' Institute of New Zealand Seminar.

Gilligan, C. (1982), In a Different Voice: Psychological Theory and Women's Development, Cambridge, Mass.: Harvard University Press.

Grillo, T. (1991), The Mediation Alternative: Process Dangers for Women, Yale Law Journal, 100: $1545-1610$.

Grills, W. (1992), Dispute Resolution in the Employment Tribunal Part One: Mediation, New Zealand Journal of Industrial Relations, 17(3): 333-346.

Hammond, S. and Harbridge, R. (1993), The Impact of the Employment Contracts Act on Women at Work, New Zealand Journal of Industrial Relations, 18(1): 15-30.

Hill, L. and Du Plessis, R. (1993), Tracing the Similarities, Identifying the Differences: Women and the Employment Contracts Act, New Zealand Journal of Industrial Relations, 18(1): 31-43.

Joychild, F. (1993), A Critique of the Law of Sexual Harassment in Aotearoa/New Zealand, Wellington: 1993 New Zealand Suffrage Centennial Women's Law Conference Papers. Conference Publishing.

MacKinnon, C. (1987), Feminism Unmodified, Cambridge, Mass.: Harvard University Press.

Maxwell, D. (1992), Gender Differences in Mediation Style and Their Impact on Mediation Effectiveness, Mediation Quarterly, 9(4): 353-364.

Menkel-Meadow, C. (1985), Portia in a Different Voice: Speculations on a Women's Lawyering Process, Berkeley Women's Law Journal, 1: 39-63.

Ryan, R. (May 1993), Impact of the ECA on Women Workers, Address to the Biennial CTU Conference.

Stamato, L. (1992), Voice, Place and Process: Research on Gender, Negotiation and Conflict Resolution, Mediation Quarterly, 9(4): 375-386.

Swarbrick, P. (1995), Sexual Harassment in the Workplace - Employer Liability, Human Rights Law and Practice, 1: 21-31. 
Williams, P. (1987), Alchemical Notes: Reconstructing Ideals from Deconstructed Rights, Harvard Civil Rights - Civil Liberties Law Review, 22: 401-433.

Wilson, M. (1994), Contractualism and the Employment Contracts Act 1991: Can They Deliver Equality For Women?, New Zealand Journal of Industrial Relations, 19(3): 256-274.

\section{Cases}

$A \vee Z$ [1992] 3 ERNZ 501; [1993] 2 ERNZ 469.

$A \& B v X Y$ Ltd (Unreported, Employment Tribunal, Christchurch, 2 March 1995, DS Miller, CT 25/95).

Airways Corp of NZ Ltd v Brunton [1994] 1 ERNZ 352.

Baussmann v Trilogy Business Systems Ltd [1992] 1 ERNZ 386.

Blomfield v Kentucky Fried Chicken [1992] 1 ERNZ 126.

Cain v HL Parker Trusts [1992] 3 ERNZ 777.

Crawford v Managh (Unreported, Employment Tribunal, Wellington, 25 August 1995, GJ Wood, WT 96/95).

Davidson v Christchurch Civic Creche [1995] 1 ERNZ 172.

Eggleston v The Firestone Tyre and Rubber Company (NZ) Ltd (Unreported, Employment Tribunal, Christchurch, 6 September 1993, GM Teen, CT 119/93).

Finau v Carter Holt Building Supplies [1993] 2 ERNZ 971.

Forbes v Colonial Mutual [1992] 1 ERNZ 42.

Fortex Group Ltd v Laxton [1994] 1 ERNZ 402.

Harding $v$ Challenge Real Estate [1992] 1 ERNZ 546.

Hobday v Timaru Girls' High School Board of Trustees [1993] 2 ERNZ 146; [1994] 1 ERNZ 724.

House v Northland Area Health Board [1991] 3 ERNZ 913.

J v M (Unreported, Employment Tribunal, Auckland, 21 July 1994, IM Davidson, AT 235/94).

$L v M[1994] 1$ ERNZ 123. 
Lavery v Trust Bank Wellington Ltd [1994] 2 ERNZ 339.

Nansen v Wellington City Council [1992] 1 ERNZ 617.

Northern Clerical IUOW v Printpac UEB Carton [1989] 2 NZILR 644.

PA O'Connor v Brass [1994] 1 ERNZ 388, 396.

Pooley $v$ NZ Society for the Intellectually Handicapped Inc (Unreported, Employment Tribunal, Auckland, 6 April 1995, BW Stephenson, AT 102/95).

Prebble v Coastline FM [1992] 1 ERNZ 52.

Proceedings Commissioner v NZ van Lines [1993] 2 ERNZ 112.

Robertson v Port Nelson Ltd [1994] 1 ERNZ 976.

Roderique v Port FM Ltd [1991] 3 ERNZ 825.

Shaffer v Gisborne Boys' High School Board of Trustees [1995] 1 ERNZ 94.

Sloggett v Taranaki Health Care [1995] 1 ERNZ 553.

Ter Haar v Eliot-Cotton Associates [1993] 1 ERNZ 371.

Trotter v Telecom Corp [1993] 2 ERNZ 659.

van Leeuwen v Skedden [1994] 1 ERNZ 624.

$X v A B$ Co Ltd [1994] 2 ERNZ 419.

X v Y Ltd \& NZ Stock Exchange [1992] 1 ERNZ 863. 